\title{
HARMONI HINDU-MUSLIM DI BALI MELALUI KEARIFAN LOKAL: STUDI DI KABUPATEN JEMBRANA
}

\section{HARMONY HINDU-MUSLIM IN BALI THROUGH LOCAL WISDOM: STUDY IN JEMBRANA DISTRICT}

\author{
Saihu \\ Institut PTIQ Jakarta \\ madesaihu@ptiq.ac.id \\ Artikel diterima 17 September 2019, diseleksi 06 November 2019, \\ dan disetujui 23 Oktober 2020
}

\begin{abstract}
This paper discusses the process of creating harmony (ethical dialogue) between Hindus and Muslims through sarana 'Urf (tradition) or local wisdom that is believed to have religious, philosophical, and sociological values as well as multicultural nuances for the Jembrana community of Bali Province. In his analysis, this paper uses the Integrative Communication Theory proposed by Kim Young Yun, focusing on the 'Urf (tradition) which is used as a means to communicate and interactbetween the tworeligiouscommunities, thus leading to the peaceful practice of Hindu society. and Muslims in Jembrana-Bali. Data sources were obtained through unstructured observations and interviews from March to July 2019 and using the case study method. The results of this study show that in order to create harmony in communication and interaction between Hindus and Muslims in Jembrana is through the traditions of Male, Ngejot, Rebana, and Mekepung. Harmonization built from the four traditions is the result of a deep sense of understanding about each other's traditions and culture or intercultural transformation so as to grow a sense of brotherhood, understanding diversity, fostering community interest between the two religious communities, and can shape the character of Hindu and Muslim communities in Jembrana to be humanist, tolerant and
\end{abstract}

\begin{abstract}
Abstrak
Tulisan ini membahas tentang proses penciptaan keharmonisan (etika dialog) antara umat Hindu dan Muslim melalui sarana 'urf (tradisi) atau kearifan lokal yang diyakini memiliki nilai-nilai religius, filosofis, dan sosiologis sekaligus bernuansa multikultural bagi masyarakat Jembrana, Provinsi Bali. Dalam analisanya, tulisan ini menggunakan Teori Komunikasi Integratif (Integrative Communication Theory) yang dikemukakan oleh Kim Young Yun, dengan memfokuskan pembahasan pada 'urf (tradisi) yang dijadikan sarana untuk berkomunikasi dan berinteraksi antar kedua umat beragama, sehingga mengarah pada praktik damai pada masyarakat Hindu dan Muslim di JembranaBali. Sumber data diperoleh melalui observasi dan wawancara tak terstruktur selama bulan Maret sampai Juli 2019 dan dengan menggunakan metode studi kasus. Hasil dari kajian ini memperlihatkan bahwa dalam rangka menciptakan keharmonisan berkomunikasi dan berinteraksi antara umat Hindu dan Muslim di Jembrana adalah melalui tradisi Male, Ngejot, Rebana, dan Mekepung. Harmonisasi yang terbangun dari keempat tradisi ini adalah lahirnya rasa pemahaman yang mendalam tentang tradisi dan budaya masing-masing atau transformasi antar budaya sehingga tumbuh rasa persaudaraan, pemahaman kebhinekaan, menumbuhkan ketertarikan antara kedua umat beragama,
\end{abstract}


inclusive, so that it leads to a process of association, integration, complementation and sublimation.

Keywords: 'Urf, Harmony, Male, Ngejot, Rebana, Mekepung.

\section{PENDAHULUAN}

Tulisan ini membahas tentang proses menciptakan keharmonisan (titik temu dialog) antara Umat Hindu dan Umat Muslim yang teraktualisasi pada beberapa 'urf (kearifan lokal). Pada konteks-konteks wilayah tertentu hal ini sangat menarik diangkat sebagai bagian dari strategi mengelola keberagaman di Indonesia. Dalam konteks Jembrana di Propinsi Bali, proses itu bertujuan untuk menciptakan harmonisasi antara kedua umat beragama. Hal ini penting untuk diwejantahkan, mengingat belakangan ini sering terjadi politik identitas, baik itu suku, agama, ras, dan antar golongan sebagai dampak dari globalisasi dan arus transnasional yang bersikeras memaksakan paham yang dianutnya. Urf atau kearifan lokal adalah salah satu dasar hukum dalam pelaksanaan ibadah dan muamalah (Abdul Haq, 2009).

Menurut Ibn Khaldun (1332-1406), selain empat dasar fikih (Alquran, Sunah, Ijma', dan Qiyas), Islam memiliki dasardasar hukum fikih yang kuat tetapi tidak terlalu prinsip. Dasar-dasar hukum itu antara lain: Istihsân, Istishâb, Istislâh, dan 'Urf. Dasar hukum ini sebatas sumber tambahan yang levelnya yang tidak signifikan (dhu'f al-madârik) serta tidak banyak dibicarakan (Khaldûn, 1992). Karena alasan itu, ia tidak berbicara tentang 'urf dan dasar-dasar yang lain ketika berbicara singkat tentang disiplin ushul figh dalam Muqaddimahnya. Di sini tampak bahwa 'urf diposisikan sebagai sumber hukum sekunder yang serta dapat membentuk karakter masyarakat Hindu dan Muslim di Jembrana menjadi humanis, toleran, dan inklusif, sehingga mengarah pada proses asosiasi, integrasi, komplementasi dan sublimasi.

Kata Kunci: 'Urf, Harmoni, Male, Ngejot, Rebana, Mekepung.

bisa dipakai setelah tidak ditemukan sumber hukum primer dan cenderung diposisikan marginal (Zahid, 2006). Walaupun demikian, 'urf yang biasa disebut "tradisi" hakikatnya sangat penting dalam penetapan hukum Islam.

Umat Islam di Indonesia, umumnya menjadikan 'urf yang dalam terminologi Nusantara berarti tradisi atau kearifan lokal sebagai dasar pengambilan hukum. Menurut al-Qarafi, dalam berdakwah, para mujtahid harus mengenal 'urf atau tradisi suatu masyarakat terlebih dahulu sebelum memberikan fatwa hukum sehingga tidak berseberangan dengan kemaslahatan umat (Al-Qarafi \& Idris, 1998). Arti penting 'urf, salah satunya dapat dilihat dari apresiasi Islam atas tradisi yang telah ada pada masyarakat Arab sejak sebelum kedatangannya. Islam lahir di tengah suatu budaya dan sistem nilai, bahkan di tengah kepercayaan dan praktik keagamaan yang telah semarak. Semua itu justru menjadi miliu dan memberikan "konteks" bagi kelahiran Islam. (Peters, 1995)

Urgensi 'urf atau kearifan lokal semakin terasa ketika Islam memasuki dunia non-Arab. Islam yang "terbungkus" budaya Arab berhadapan dengan budaya dan tradisi yang berbeda. Tidak jarang banyak para tokoh kurang begitu memahami eksistensi keragaman budaya dan tradisi luar, sehingga cenderung menganggapnya sebagai "sesat" dan tidak islami. Eksistensi tradisi dan kearifan lokal dalam aktivitas keagamaan memunculkan anggapan bahwa Islam 
yang benar dan murni adalah "Islam yang bercorak Arab". Padahal "urf atau kearifan lokal yang ada di masyarakat dapat dijadikan sebagai mekanisme sosio-kultural dan dialog yang diyakini dan telah terbukti ampuh sebagai sarana dalam menggalang persaudaraan dan solidaritas antar warga yang telah melembaga dan mengkristal dalam tatanan sosial dan budaya (Azra, 2002).

Keragaman agama, tradisi, dan budaya Indonesia merupakan suatu kenyataan sejarah yang lahir dari kondisi geografis Nusantara. Sebagai sebuah kenyataan sejarah, agama dan kebudayaan dapat saling memengaruhi, karena keduanya memiliki nilai dan simbol. Agama merupakan simbol yang melambangkan nilai ketaatan dan ketakwaan kepada Tuhan. Sementara kebudayaan mengandung nilai dan simbol agar manusia bisa hidup di dalamnya. Agama memerlukan sistem simbol, atau dengan narasi yang berbeda, agama memerlukan kebudayaan. Namun, antara agama dan kebudayaan harus dibedakan. Agama adalah sesuatu yang final, abadi, universal, dan tidak mengenal perubahan (absolut), karena yang umumnya berubah adalah tafsir dari teks-teks suci keagamaan yang dikontekstualisasikan dengan situasi dan kondisi serta memiliki kapasitas untuk mengakomodasi berbagai situasi sosial, budaya, ekonomi, politik dan lain sebagainya (Saeed, 2016). Lain halnya dengan agama, kebudayaan umumnya bersifat relatif, partikular, dan temporer. Agama tanpa kebudayaan memang dapat berkembang, namun hanya sebagai agama pribadi, karena tanpa kebudayaan, agama sebagai kolektivitas tidak akan mendapat tempat (Kuntowijoyo, 2001).

Agama dan kebudayaan sesungguhnya memiliki persamaan, antara lain; pertama, agama dan budaya adalah sistem nilai dan sistem simbol; kedua, baik agama maupun kebudayaan mudah sekali terancam setiap kali ada perubahan. Dalam perspektif ilmuilmu sosial, agama didefinisikan sebagai sistem nilai yang memuat sejumlah konsepsi mengenai konstruksi realitas yang berperan besar dalam menjelaskan struktur tata normatif dan tata sosial yang berfungsi untuk memberi pemahaman sekaligus mampu menafsirkan dunia sekitar. Sementara kebudayaan merupakan ekspresi cipta, karya, dan karsa manusia (dalam masyarakat tertentu) berisi nilai-nilai dan pesanpesan religiositas, wawasan filosofis, dan kearifan lokal (Sumbulah, 2012).

Sebagai sistem pengetahuan, agama merupakan sistem keyakinan yang dipenuhi dengan ajaran-ajaran moral serta petunjuk kehidupan yang harus dipelajari, ditelaah, dan dipraktikkan oleh manusia dalam kehidupannya. Dalam hal ini, agama memberikan petunjuk mengenai yang baik dan buruk, yang pantas dan tidak pantas, dan yang tepat dan tidak tepat, sehingga nilai-nilai agama dapat membentuk serta mengembangkan perilaku manusia dalam kehidupan sehari-hari (Paisun, 2010). Ketika agama berfungsi sebagai sistem simbol, terdapat simbol-simbol tertentu yang digunakan untuk mengaktualisasikan ajaran agama yang dianutnya. Simbol-simbol itu bisa berupa perbuatan, perkataan, benda-benda, kalimat-kalimat suci atau sastra, dan sebagainya. Perbuatan sujud misalnya, merupakan bentuk simbolisasi atas kepasrahan dan penghambaan penganutnya pada sang pencipta. Sujud merupakan simbol totalitas kepasrahan hamba dan pengakuan secara sadar akan ke-maha besaran Allah Swt (Al-Humaidy, 2017).

Ajaran Islam yang termuat di dalam teks-teks suci (Alquran dan Hadis) adalah ajaran yang merupakan sumber asasi, dan ketika sumber itu digunakan atau diamalkan di suatu wilayahsebagai pedoman kehidupan-maka 
bersamaan dengan itu, tradisi setempat bisa saja mewarnai penafsiran masyarakat setempat terhadap teks suci tersebut. Oleh karena penafsiran itu bersentuhan dengan teks suci, maka simbol yang diwujudkannya juga merupakan sesuatu yang sakral. Dialog antaragama, merupakan pemenuhan komunikasi yang berlaku di masyarakat yang multikultural. Apalagi jika dilihat dalam adagium ushul figh (teori legal hukum Islam) menyatakan bahwa: "sesuatu yang membuat sebuah kewajiban agama tidak terwujud tanpa kehadirannya, akan menjadi wajib pula" (mâ la yatîmu al wajibu illa bihi fahuwa wâjibun). Komunikasi atau kerja sama tidak akan terlaksana tanpa dialog, maka oleh karena itu dialog antar agama juga tentunya menjadi kewajiban. Dalam alQur'an juga dinyatakan "Sesungguhnya telah Ku-ciptakan kalian sebagai laki-laki dan perempuan, dan Ku-jadikan kalian berbangsabangsa dan bersuku-suku agar kalian saling mengenal" (QS.49:13).

Atas dasar ini, peneliti tertarik untuk meneliti mengenai harmoni antarumat Hindu dan Muslim di Jembrana. Melalui penelitian ini, ada usaha untuk mencari jawaban dari kerukunan yang tercipta di Jembrana melalui teori komunikasi integratif (Integrative Communication Theory). Teori ini dikemukakan oleh Kim Young. Menurutnya, bahwa terdapat interaksi makhluk sosial dalam masyarakat. Namun, kemampuan individu untuk berkomunikasi sesuai dengan norma-norma dan nilai-nilai budaya lokal tergantung pada proses penyesuaian diri atau adaptasi para pendatang (Gudykunts, William B, 2003). Kim mengidentifikasi empat hal yang menjadi faktor dalam adaptasi, yaitu:

Pertama, komunikasi personal (personal communication), yaitu apabila seseorang merasakan adanya hal-hal yang terdapat dalam lingkungannya, kemudian memberi makna serta mengadakan reaksi terhadap objek maupun orang lain yang terdapat dalam lingkungannya tersebut. Dalam tahap ini terjadi proses penyesuaian dengan menggunakan kompetensi komunikasi pribadi yang diturunkan menjadi tiga bagian yaitu kognitif, afektif, dan operasional. Aspek kognitif dari kompetensi komunikasi dipisahkan ke dalam pengetahuan individu tentang sistem komunikasi, pemahaman kultural, dan kompleksitas kognitif. Aspek afektif dalam kompetensi komunikasi di sini merupakan komposisi dari motivasi adaptasi individu, fleksibilitas identitas, dan estetika orientasi bersama. Selanjutnya, aspek operasional atau kemampuan untuk mengekspresikan kognitif dan pengalaman afektif individu, terlihat melalui aspek perilakunya atau secara spesifik menunjukkan kompetensi komunikasinya itu. Pencapaian kompetensi komunikasi diperlukan untuk memenuhi kebutuhan umum manusia, yaitu mengatasi lingkungannya terutama jika itu adalah lingkungan baru.

Kedua, komunikasi sosial tuan rumah (host social communication), dan komunikasi sosial etnis (ethnic social communication). Keduanya sama-sama terdiri dari dua macam komunikasi, yaitu komunikasi interpersonal dan komunikasi massa. Komunikasi interpersonal mengacu pada interaksi antara individu yang satu dengan yang lainnya, pada level interpersonal. Bedanya jika host social communication terjadi antara individu pendatang dengan individu dari budaya setempat sehingga ada perbedaan budaya antara keduanya, sedangkan ethnic social communication, terjadi antara individuindividu dengan latar belakang budaya yang sama, misalnya individu pendatang berinteraksi dengan individu yang mempunyai asal dan budaya yang sama dengannya. Adapun komunikasi masa di sini sehubungan dengan sarana-sarana yang digunakan dalam mendistribusikan dan mengabadikan budaya. Hal tersebut meliputi baik media seperti radio, 
televisi, surat kabar, dan internet; dan juga non media yang berbasis institusi seperti sekolah, agama, kantor, bioskop ataupun tempat umum apa pun, di mana komunikasi terjadi dalam bentuk ritual budaya. Komunikasi masa ini berfungsi sebagai tenaga dalam proses adaptasi dengan melakukan transmisi topik peristiwa-peristiwa, nilai-nilai sosial, norma perilaku, perspektif interpretasi lingkungan tradisional. Komunikasi massa ini berarti adanya interaksi antara individu dengan massa baik melalui media maupun non media, bedanya jika host social communication interaksi terjadi antara individu pendatang dengan budaya setempat yang baru baginya, sedangkan ethnic social communication interaksi terjadi antara individu pendatang dengan budaya asalnya atau yang sudah dikenalnya.

Ketiga, lingkungan (environment), yang dibagi menjadi penerimaan tuan rumah, tekanan akan adanya kesesuaian dari tuan rumah, dan kekuatan kelompok etnis. Penerimaan tuan rumah mengacu pada kemauan dari budaya setempat untuk menerima dan mengakomodasi pendatang melalui kesempatan ikut berperan serta dalam komunikasi sosial. Dari perspektif pendatang, hal ini dapat dianggap akses untuk masuk atau kesempatan untuk mendapatkan kontak. Tekanan akan adanya kesesuaian dari tuan rumah merupakan kombinasi dari tekanan yang sadar maupun tidak sadar terhadap pendatang untuk mengadopsi praktik-praktik budaya setempat, dan toleransi tuan rumah dalam menghormati praktik-praktik budaya yang berbeda dari budaya mereka. Salah satu faktor yang penting di sini adalah adanya perbedaan antara ideologi asimilatif atau pluralis. Ideologi asimilatif mendorong adanya kesesuaian, sedangkan ideologi pluralis mendorong adanya kekhasan etnis. Hal tersebut membawa kepada kekuatan kelompok etnis yang merujuk pada kekuatan kelompok dari budaya atau etnis yang sama dengan asal individu pendatang.

Keempat, kecenderungan (predisposition), mengacu pada keadaan pribadi pendatang ketika mereka tiba dalam kelompok budaya setempat, jenis latar belakang yang mereka miliki, dan jenis pengalaman yang mereka punya sebelum bergabung dengan budaya setempat.

Jika ditinjau lebih dalam, model interaksi antara umat Hindu dan Muslim sejalan dengan empat langkah teori komunikasi integratif Kim Young Yun, dengan menjadikan 'urfatau kearifan lokal sebagai sarana untuk mengaktualisasikan diri baik dalam komunikasi personal atau sikap umat Hindu sebagai tuan rumah dalam menciptakan komunikasi antaretnis melalui praktik ideologi asimilatif dan pluralis, sehingga menjadi komunikasi yang khas antara umat Hindu dan Muslim di Jembrana. Tentu dalam menciptakan itu diperlukan, dalam hal ini umat Muslim, untuk menyesuaikan diri dengan lingkungan sehingga budaya dan tradisi yang tadinya berbeda dapat berjalan seiring, saling melengkapi, dan tidak menafikan salah satu dari keduanya.

\section{METODE}

Kajian ini adalah penelitian lapangan yang sering digunakan secara bersamaan dengan studi etnografi bersifat eksploratif (Bailey, 1982), bertujuan untuk memperoleh gambaran tentang proses menciptakan keharmonisan melalui tradisi-tradisi lokal (Male, Ngejot, Rebana, Mekepung) sebagai sarana berinteraksi antar komunitas Hindu dan Muslim. Untuk tujuan tersebut, maka penelitian ini menggunakan pendekatan kualitatif. Sebab dalam penelitian kualitatif, peneliti mengkaji sesuatu dalam setting natural dan menafsirkan fenomena terkait dengan makna. Penelitian kualitatif sebagaimana yang dikatakan oleh Sharan 
B. Merriam, memiliki empat karakteristik utama yaitu: 1) menekankan pada proses, pemahaman, dan makna; 2) peneliti berfungsi sebagai instrumen utama dalam pengumpulan dan analisis data; 3 ) proses bersifat induktif; dan 4) hasilnya bersifat deskripsi yang kaya (Merriam, 2009).

Adapun metode yang digunakan dalam penelitian ini adalah metode studi kasus. Sebagai salah satu varian dalam penelitian kualitatif, studi kasus memberikan uraian dan penjelasan komprehensif mengenai suatu setting tertentu, dokumen, atau suatu kejadian tertentu (Knopp, 1998). Dengan mempelajari secara maksimal mengenai hal ini, peneliti ingin mendapatkan pandangan yang lengkap dan mendalam mengenai aktualisasi tradisi-tradisi di Jembrana. Sedangkan teknik pengumpulan data dalam penelitian ini dilakukan dengan cara observasi, in-depth interview, dan dokumentasi dari beberapa tokoh umat Hindu dan Muslim. Observasi ini diarahkan untuk memahami setting of harmonious kondisi sosial masyarakatnya.

\section{PEMBAHASAN}

\section{Menelisik Empat Kearifan Lokal Pencipta Harmoni}

Di wilayah Jembrana sebagian besar kebudayaan, tradisi, dan kultur masyarakatnya bersumber dari sistem ide yang berasal dari agama Hindu, sehingga terkadang sangat sulit untuk memahami kehidupan sosial masyarakat Bali, tanpa pemahaman tentang agama Hindu, khususnya Hindu Siwa-Siddhanta. Orang yang hendak mempelajari Bali tanpa terlebih dahulu memahami agama Hindu, akan sulit membedakan agama dan budaya. Karena, secara filosofis, genealogi agama sebagai sebuah praktik di Bali, merupakan buah dari ajaran filsafat mimamsa, yaitu sebuah ajaran filsafat yang menitikberatkan pada ritualritual keagamaan (Burhanuddin, 2012).
Sementara umat Islam yang datang ke Jembrana sekitar abad ke 17 adalah orangorang keturunan dari Kesultanan Wajo Sulawesi Selatan, Bugis, dan terakhir Pontianak (Kuala Trengganu) yang membangun peradaban baru di Jembrana bersumber dari ajaran Islam.

Kedua umat beragama tersebut selanjutnya bersama-sama membangun sebuah peradaban baru di Jembrana yang didasarkan pada keyakinan (agama dan budaya) masing-masing. Kemampuan mereka berkomunikasi inilah yang mampu membuat kondisi masyarakatnya menjadi harmonis dalam perbedaan, yang oleh Kim Young Yun disebut terjadinya sebuah proses integrative communication. Menurut Santika Putra, apa yang membuat relasi sosial di Jembrana berjalan begitu indah, semakin kuat dan semakin nyaman, tidak ada dominasi, dikotomi, diskriminasi serta yang lagi hangat sekarang "kriminalisasi" di antara elemen masyarakat, karena masyarakat Jembrana memiliki pengkristalan budaya yang tertanam pada setiap individu sejak mereka duduk di bangku sekolah dasar, entah itu Hindu, Muslim, Kristen, dan sebagainya. Budaya yang dimaksud adalah budaya yang bisa menerima atau adoptif dan budaya bisa menyesuaikan atau adaptif (Wawancara dengan IBK. Dharma Santika Putra, 1 Mei 2019). Sementara menurut KH. Ahmad Muzakki, etika dialog bagi warga Muslim Jembrana dengan warga Hindu Jembrana menggunakan pendekatan wasathan (tengah-tengah), tidak ekstrem dan tidak pula sekuler. Sebagai ketua MUI Kabupaten Jembrana, dia selalu mengingatkan kepada umat Islam di Jembrana, sebagaimana yang disebutkan dalam Alquran, yaitu "Jangan terlalu berlebih-lebihan dalam beragama”(QS.5:77). Maksudnya adalah jangan sampai umat Islam Jembrana, terpengaruh oleh kelompok-kelompok radikal yang menganggap apa yang mereka lakukan adalah yang paling benar, karena hal 
itu akan merusak hubungan antarumat beragama dan interumat beragama (Wawancara dengan KH. Ahmad Muzakki, 2 Mei 2019).

Kedua budaya ini didasarkan pada strategi luhur dalam berinteraksi di tengah masyarakat Bali yang sudah dikenal sejak zaman dahulu, yaitu Desa, Kala, dan Patra. Desa berarti tempat, kala berarti waktu, dan patra berarti keadaan atau situasi di mana kita berada. Budaya Adoptif di sini diasumsikan bahwa masyarakat Jembrana tidak menafikan perubahan sosial yang pasti tidak mungkin dihindari. Ketika terjadi perubahan sosial dan perkembangan zaman, maka sudah sewajarnya harus bisa menyesuaikan (adaptif) (Dharmayuda, 1995). Namun, hal ini akan terjadi jika kedua umat beragama memiliki personal communication yang baik antara host social dan ethnic social. Perjumpaan host social dan ethnic social di Jembrana melahirkan sebuah solidaritas yang tinggi antara umat Hindu dan Muslim yang oleh masyarakat Muslim di Jembrana dikenal dengan istilah awak mesedare (kita semua bersaudara).

Masyarakat Jembrana berprinsip bahwa adanya perbedaan keyakinan tidak harus disamakan dan tidak harus dipertentangkan, karena bagi mereka, masing-masing memiliki kepercayaan (akidah) yang dianggap benar. Arnawa, menuturkan, "Setiap saya akan mengadakan upacara keagamaan, temanteman saya yang beragama Islam ikut turut serta membantu mempersiapkan peralatan atau sarana yang saya perlukan dalam upacara tersebut." Ia juga menceritakan memiliki saudara sepupu yang pindah agama menjadi seorang Muslim karena menikah dengan muslimah. Perbedaan keyakinan dalam lingkungan keluarganya, tidak membatasi dirinya untuk selalu berkomunikasi dan bekerja sama dalam hal muamalat. Baginya hidup rukun dan saling tolong- menolong sangat penting. Karena kalau sudah rukun, tentu saja untuk mencapai kesejahteraan materi akan dimudahkan oleh Tuhan (Wawancara dengan Ida Bagus Arnawa, tanggal 7 April 2019).

Model dialog di antarumat Hindu dan Muslim umumnya dilakukan secara tidak terstruktur dan mencair begitu saja, seolah-olah tidak ada yang perlu didialogkan atau dibicarakan. Umat Hindu dan Muslim di Bali sudah mengerti dan bersikap dewasa terhadap perbedaan keyakinan di antara mereka yang mempunyai nilai positif untuk saling melengkapi dan tidak mempunyai nilai negatif untuk saling membenci. Beberapa tradisi atau kearifan lokal setempat yang dijadikan sarana untuk berdialog adalah:

\section{a. Tradisi Male}

Tradisi male merupakan tradisi keagamaan yang berasal dari umat Islam. Sekalipun tradisi male merupakan tradisi yang berasal Islam, namun dalam pelaksanaannya melibatkan umat Hindu. Perbedaan agama tidak menjadi penghalang dalam pelaksanaan tradisi ini, karena memang umat Islam di Jembrana sangat terbuka terhadap keanekaragaman (Saihu, 2019). Tradisi male merupakan bentuk ritual keagamaan yang dilakukan oleh setiap keluarga dan masyarakat Muslim di Jembrana, yaitu ketika masyarakat Muslim Jembrana memperingati Maulid Nabi Muhammad saw. Maulid Nabi dan male merupakan satu kesatuan yang tidak dapat dipisahkan dalam aktivitas ritualnya bagi masyarakat Jembrana. Male adalah telur yang direbus dengan tidak mengupas (menghilangkan kulit luar) yang dirangkai sedemikian rupa dalam berbagai bentuk yang memiliki nilai estetika dan filosofi keagamaan yang tinggi. Bentuk male ada yang berupa "pajegan" atau bentuk lainnya dengan menusukkan puluhan telur rebus ke batang pohon pisang yang dihiasi kertas warna warni, ada juga yang menyerupai kapal-kapalan, pepohonan (bonsai), dan

\begin{tabular}{l|l} 
Jurnal Multikultural \& Multireligius Vol. 19 & No. 1
\end{tabular} 
binatang unta. Rangkaian atau bentuk telur ini, oleh masyarakat Muslim Jembrana disebut dengan male. Male juga biasanya dijadikan bingkisan (berkat) bagi umat maupun undangan yang hadir. Apalagi dalam keluarga itu ada kelahiran, maka dalam "menyelamati" bayi yang baru lahir tersebut, wajib menghadirkan male sebagai ucapan syukur kepada Allah Swt.

Ritual ini dimulai dengan berkeliling kampung sambil membawa telur yang telah dibentuk dengan berbagai corak atau sesuai dengan selera yang diinginkan pembuatnya seperti pura, perahu, masjid, rumah, bonsai, dan lain-lain. Male yang diarak mengelilingi kampung ini dikawal oleh pasukan khusus dengan menggunakan pakaian adat Bali yang di sebut pager uyung, yaitu kaum kesatria adat yang diwakili oleh beberapa orang dari umat Islam maupun Hindu. Dalam perjalanannya mengelilingi kampung, male yang diarak diringi dengan pembacaan asrakal, yaitu membaca salawat serta puji-pujian kepada Nabi Muhammad saw. sambil menabuh rebana atau marawis.

Setelah selesai mengelilingi kampung, kemudian seluruh male atau telur yang telah dihiasi tersebut, dikumpulkan di dalam masjid sambil diiringi bacaan salawat. Telur yang dihiasi dan diwarnai, lalu ditusuk bambu kemudian ditancapkan ke pohon pisang, terlihat seperti pohon pisang berbuah telur (pajegan) yang dipajang saat maulid. Setelah seluruh male dipajang, para jamaah bersenandung salawat secara berjamaah dilanjutkan dengan membaca syair salawat diba' yang berisi tentang sejarah hidup Nabi Muhammad saw. sebagai tanda pengungkapan rasa cinta mereka kepada Nabi. Selanjutnya pembacaan doa menjadi acara penutup sebelum telur-telur dibagikan kepada masyarakat yang hadir di sana. Ketika telur dibagikan, masyarakat sangat antusias untuk mendapatkan male, walau harus berdesak-desakan dan berebut, mereka percaya bahwa mereka mendapat berkah serta keselamatan dari male yang telah didoakan oleh para ulama atau rohaniawan tadi.

Tradisi male yang umumnya selalu dilaksanakan di wilayah Jembrana, sebagaimana diutarakan oleh Muzakki, mengandung nilai-nilai luhur yang dibutuhkan dalam rangka menciptakan kehidupan yang harmonis. Nilai-nilai luhur itu antara lain: nilai etika, estetika, dan nilai sosial. Implementasi dari nilai-nilai tersebut dapat dilihat dari: pertama, nilai etika. Proses arak-arakan bertujuan untuk memberitahukan kepada khalayak ramai khususnya warga yang beragama Hindu (umat mayoritas), bahwa umat Muslim mohon izin sedang melaksanakan kegiatan peringatan hari besar keagamaan, yang dalam perjalanannya tidak hanya diikuti oleh umat Muslim, tetapi juga diikuti oleh umat Hindu, bahkan banyak dari proses arak-arakan dikawal oleh pecalang (polisi adat Bali); kedua, nilai estetika. Nilai estetika dalam tradisi male dapat dilihat melalui bentuk atau model male itu sendiri yang mengandung nilai seni yang tinggi. Bentuk nilai seni lainnya adalah dalam pembacaan asrakalan pada saat male itu diarak keliling kampung. Dengan menggunakan pakaian hasil akulturasi budaya Islam dan Hindu peserta pawai seolah-olah hanyut ke dalam suasana arak-arakan; ketiga, nilai sosial. Nilai sosial yang terdapat dalam tradisi male ini adalah sebagai sarana berbagi kepada masyarakat luas, baik mereka yang beragama Islam ataupun mereka yang beragama Hindu (Wawancara dengan KH. Ahmad Muzakki, 4 Maret 2019).

Dalam tradisi ini tidak dibatasi oleh umat Muslim saja, tetapi banyak dari umat Hindu yang mengikuti prosesnya. Lalu telur sebagai bahan 
utama dari male di bagikan kepada seluruh peserta Maulid Nabi dengan tanpa memandang perbedaan agama. Aktivitas seperti itu adalah bentuk nyata dari tradisi masyarakat Jembrana yang secara sadar bersama-sama untuk hidup rukun dalam keberagaman. Potret yang terjadi di Jembrana adalah wujud dari proses dialektika harmonis antara umat Hindu dan Muslim di Jembrana-Bali. Mereka sadar bahwa mereka berbeda dari segi agama, tetapi perbedaan agama bukanlah menjadi sekat atau suatu yang dapat menghalangi untuk hidup rukun bersama-sama dalam membangun peradaban atau menciptakan sebuah masyarakat madani antara umat Islam dan Hindu di Jembrana.

\section{b. Tradisi Ngejot}

Aktivitas saling membantu antara umat Hindu dan Muslim di Jembrana dikenal dengan istilah metetulung yang berarti saling bantu-membantu dalam kegiatan keagamaan dan sosial (M. Saihu, 2019). Aktivitas saling tolong-menolong terjadi ketika ada warga kampung atau warga desa adat memiliki pekerjaan yang memerlukan bantuan tenaga baik diminta (ngidih tulung) atau tidak diminta (mesuaka). Walaupun tidak diminta, warga biasanya memberikan bantuan sukarela karena merasa bersaudara (menyama). Metetulung, tidak hanya sebatas saling membantu dalam kegiatan bermasyarakat, tetapi juga dalam hal pengobatan, karena banyak warga Hindu yang datang minta bantuan pengobatan kepada para kiai atau ustaz di Jembrana (Wawancara dengan I Komang Arsana, 7 April 2019).

Hubungan masyarakat Muslim dan Hindu diperkuat dengan tradisi ngejot. Tradisi itu muncul ketika salah satu warga, baik Hindu maupun Muslim memiliki pekerjaan adat, mengundang warga lain, atau mengungkapkan rasa syukur dengan mengirimkan makanan.
Ketika ada salah satu keluarga Muslim yang mengadakan acara pernikahan, kelahiran, atau perayaan, maka ia akan mengundang warga Hindu dan atau warga Muslim mengantarkan makanan. Selanjutnya, warga yang diundang pun akan hadir dengan membawa beras, gula, kopi (sembako) dan lain sebagainya (Saihu, Abd. Aziz, Fatkhul Mubin, 2020).

Demikian halnya ketika dalam bulan Ramadan, salah satu bentuk penghormatan yang diberikan umat Hindu kepada warga Muslim adalah dengan ngejot makanan berbuka, seperti ketupat, buah, es engkud (air kelapa muda), dan lain sebagainya (A. M. Saihu, 2019). Jika dilihat dari sejarahnya, umat Islam melakukanngejot bermula sejak masuknya Islam di Bali, yang tentu saja terjadi akulturasi atau asimilasi kebudayaan sejak ratusan tahun silam, sehingga tradisi ngejot tidak saja dilaksanakan oleh umat Hindu di Jembrana, tetapi umat Islam pun melaksanakan tradisi ini. Ngejot bagi komunitas Muslim, merupakan wujud dari rasa persaudaraan dan kemanusiaan kepada umat Hindu di Jembrana yang biasa dilakukan pada saat hari raya Idul Fitri, Idul Adha, atau ketika umat Islam mempunyai hajatan dan atau acara keagamaan lainnya.

Fenomena itu dibenarkan oleh Arsana (Ketua Parisada Hindu Dharma Indonesia), Kabupaten Jembrana. Ia menuturkan "Seringkali ketika saya sedang merayakan Galungan atau Kuningan dan acara hajatan lainnya, saya selalu berfikir untuk ngejot atau mengirim makanan kepada saudara-saudara saya yang beragama Islam, tentu saja jenis makanan yang akan saya berikan tidak bertentangan dengan syariat Islam." Dia juga menambahkan, bahwa dampak positif dari tradisi ngejot ini sangat luar biasa dalam menjaga kerukunan dan mempererat rasa persaudaraan antar sesama umat beragama dan tradisi ini tidak akan pernah hilang, karena 
pengenalan serta pengamalan tradisi ini sudah ditanamkan sejak dini terutama di lingkungan keluarga (Wawancara dengan I Komang Arsana, 7 April 2019).

Tradisi ngejot ini adalah sebagai sarana penguat ukhuwah insaniyah (persaudaraan antar sesama manusia), dan ukhuwah wathaniyyah (persaudaraan sebangsa setanah air) (Wawancara dengan Ali Rahman, 7 April 2019). Tradisi ini merupakan salah satu tradisi sebagai bentuk komunikasi integratif antara umat Hindu dan Muslim di Wilayah Jembrana yang secara tidak langsung memberikan dampak positif dalam memantapkan kerukunan hidup beragama yang telah diwujudkan selama ini. Terpeliharanya tradisi ngejot ini dapat dijadikan dasar untuk menciptakan kemesraan, kedamaian, serta menguatkan tali persaudaraan antara umat Hindu dan Islam di Jembrana.

Dengan mengantarkan makanan antar pemeluk agama pada hari-hari besar keagamaan, diharapkan dapat mempererat tali persaudaraan dan rasa kebersamaan antara satu dengan yang lain. Ngejot, sebenarnya merupakan tradisi umat Hindu di Bali, yaitu memberikan makanan kepada para tetangga. Ini adalah sebuah tradisi yang unik dan turun-temurun dari masyarakat Pulau Bali. Ngejot juga dapat diasosiasikan dengan berbagi makanan atau jotan kepada para tetangga dan sanak keluarga. Bagi umat Hindu, tradisi ini di gelar pada Hari Raya Galungan, Kuningan, dan Hari Raya Nyepi, dan biasanya makanan yang diberikan berupa makanan siap saji, kue, serta buah-buahan. Tradisi ini merupakan simbol kemesraan dan tali kasih persaudaraan umat Hindu di Bali.

\section{c. Tradisi Rebana}

Bentuk lain dari tradisi yang menjadi kearifan lokal Jembrana sebagai hasil dari proses dialektika kebudayaan umat Islam dan masyarakat Hindu adalah kesenian rebana. Dalam tradisi rebana, lirik dan syair bernapaskan Islam menggunakan bahasa Arab ataupun lagulagu Melayu, namun agar mudah diterima masyarakat sekitar, para seniman rebana ini mengaransemen lagu-lagu tersebut dengan irama khas Bali. Dengan begitu, masyarakat Jembrana yang sebagian besar beragama Hindu akan lebih mudah menerima dan menyukai kesenian ini dan makna syiar yang menjadi tujuan utama dapat tersampaikan dengan efektif.

Menurut Arnawa, semua masyarakat Jembrana mngetahui bahwa kesenian rebana atau burdah ini berasal dari umat Muslim. Untuk mempererat tali persaudaraan antara umat Hindu dan Muslim, rebana di Jembrana berbeda dengan rebana atau burdah di daerah lain. Perbedaan tersebut pada alat musik yang digunakan, pakaian para pemain rebana, serta lirik yang dibawakan. Sebagian besar lirik yang dibawakan bercerita tentang kerukunan dan toleransi antara umat Hindu dan Muslim di Jembrana yang pada sekitar abad ke-17 bersamasama hidup rukun, bekerja sama dalam membangun Jembrana. Alat musik rebana juga menggunakan alat musik tradisional Bali. Begitu juga dengan pakaian pemain rebana menggunakan pakaian adat Bali ditambah jilbab sebagai identitas dari Muslimah. Kesenian atau rebana ini, sering dipertunjukkan pada saat maulid Nabi Muhammad saw. dan juga di acara khitanan.

Di Desa Air Kuning misalnya, masyarakatnya melaksanakan tradisi rebana, dalam rangka menyambut bulan suci Ramadan, dan masih berlangsung sampai sekarang. Yang unik dalam tradisi ini adalah tidak saja diikuti oleh umat Muslim, tetapi juga diikuti oleh umat Hindu. Selain untuk menyemarakkan acara tersebut, juga menjadi upaya untuk membangun toleransi antarumat beragama. Penduduk Air Kuning, memainkan tabuh rebana menggunakan 
teknik khusus. Biasanya tabuh rebana ini juga diiringi dengan lirik berbahasa Arab dan bahasa Melayu dengan irama khas Bali. Mereka percaya bahwa dengan tradisi tersebut, akan membuat ibadah puasa lebih damai khususnya di desa Air Kuning ini (Wawancara dengan Ida Bagus Arbawa, 9 April 2019).

Bahkan menurut Indagosa, tradisi kesenian rebana dari Jembrana ini pernah mewakili Bali dalam Festival Istiqlal di Jakarta tahun 1995. Sebagai Bupati, pada waktu itu, ia mengirimkan kesenian rebana yang para pemain atau penabuh alat musiknya berasal dari umat Hindu, dan umat Islam menggunakan pakaian adat Bali. Lirik yang dibawakan pada festival tersebut, seperti pada umumnya berupa salawat, syair-syair keagamaan, akan tetapi mayoritas para pemainnya beragama Hindu. Sebaliknya ketika lirik yang dibawakan itu berupa kidung Bali, maka para pemainnya musiknya beragama Islam. Sebagai Bupati Jembrana pada waktu itu, ia berpesan kepada seluruh kontingen festival Istiqlal tersebut, bahwa ini tidak hanya sekadar mengikuti acara festival, akan tetapi ingin menunjukkan kepada masyarakat Indonesia bentuk toleransi umat beragama di Bali, sekaligus merupakan bukti sahih proses pengejawantahan kerukunan umat beragama sebagai fenomena luhur yang ada di wilayah Jembrana (Wawancara dengan Ida Bagus Indagosa, 9 April 2019).

\section{d. Tradisi Mekepung}

Salah satu kebudayaan dan tradisi di Jembrana sebagai proses dari dialektika Hindu-Muslim di daerah ini adalah tradisi mekepung (balapan sapi khas Jembrana). Mekepung, merupakan ciri khas masyarakat agraris Jembrana dalam mensyukuri hasil panen padinya. Masyarakat Jembrana hingga hari ini masih tetap melestarikan kebudayaan ini, karena dalam budaya ini ada banyak manfaat yang dapat diambil, antara lain: rasa kebersamaan, gotong royong, toleransi, dan mempunyai makna filosofissosiologis, yaitu memiliki semangat untuk berlomba-lomba dalam mencari keberkahan dan kebaikan. Dalam Bahasa Indonesia, mekepung berarti berkejarkejaran. Dalam tradisi ini digunakan dua pasang kerbau yang saling berkejarkejaran untuk menjadi pemenang. Tradisi ini awalnya muncul dari kegiatan membajak sawah yang dilakukan secara gotong royong oleh para petani selama musim tanam di sawah. Dalam kegiatan membajak sawah digunakan dua ekor kerbau yang menarik bajak (lampit) yang ditunggangi oleh seorang joki atau sais. Dari aktivitas gotong royong membajak sawah tersebut, lalu mulailah timbul rasa untuk saling mengadu kekuatan kerbau mereka masing-masing. Hal iniliah yang di sinyalir menjadi cikal bakal adu balap kerbau yang dinamakan mekepung (Widiyanto, 2015).

Tradisi mekepung di sawah ini berkembang sekitar tahun 1930-an. Sais/ jokinya berpakaian ala prajurit kerajaan Bali zaman dulu, yaitu memakai destar, selendang, selempod, (celana panjang tanpa alas kaki dan di pinggang terselip sebilah pedang yang memakai sarung poleng atau warna hitam putih). Berselang beberapa lama, tradisi mekepung di tengah sawah berlumpur dan para sais atau joki selalu kotor dilumuri lumpurtradisi mekepung kemudian berkembang menjadi mekepung di jalan-jalan sekitar persawahan (tegalan) (Widianingsih, 2014). Tradisi mekepung di jalan-jalan persawahan (tegalan) berkembang mulai tahun 1960-an dengan dibentuknya organisasi mekepung yang terdiri dari dua kelompok yang diberi nama "Regu Ijo Gading Timur" dengan lambang bendera warna merah dan kelompok "Regu Ijo Gading Barat" dengan lambang bendera warna hijau (Sudiatmaka, 2016).

Mekepung di tegalan tidak lagi menggunakan lampit, melainkan pedati 
atau gerobak dengan ukuran yang kecil dipenuhi hiasan dan ukiran yang sangat menarik sebagai bentuk dari estetika Bali. Dalam aksinya, para joki menggunakan busana tradisional, yaitu; memakai destar batik, baju lengan panjang, memakai selempod, memakai celana panjang, dan memakai sepatu tetapi tidak menyelipkan pedang pada pinggang. Dalam tiap tahunnya, mekepung selalu rutin dilaksanakan, yaitu pada saat para petani selesai panen di sawah (antara bulan Juli sampai Oktober) yang diikuti dan semarakkan dengan kegiatan lainnya, seperti orkes dangdut, tari bumbung, dan sabung ayam (Wawancara dengan Ida Bagus Indagosa, tanggal 9 April 2019).

Selain menjadi sumber pengetahuan, masyarakat Jembrana meyakini bahwa budaya ini juga memiliki dimensi sistem struktural yang kuat. Karena, sebagai sebuah sistem gagasan, tindakan, dan hasil karya manusia dalam kehidupannya, mekepung juga merupakan sarana belajar sekaligus merupakan sarana untuk mencarikan beberapa struktur kebudayaan yang terkesan eksklusif. Berdasarkan hasil pengamatan, strukturisasi budaya di Jembrana dapat dibedakan menjadi dua, yaitu; struktur budaya dari dalam dan struktur budaya dari luar. Struktur budaya dari dalam cenderung bersifat ekspresif dan memiliki ruang yang luas sehingga berpeluang untuk berkembang secara variatif. Hal ini dapat terjadi, karena struktur dalam menjadi esensi sekaligus pembentuk kepribadian dan penanaman nilai-nilai kebudayaan yang merupakan sinergi antara tradisi dan agama Hindu yang berintikan nilai-nilai religi, etika, estetika, dan solidaritas.

\section{Internalisasi Nilai Tri Hita Karana dalam Praktik Kearifan Lokal}

Melalui empat tradisi di atas yaitu, tradisi male, ngejot, rebana, dan mekepung yang berkembang di Jembrana, menjadi sebuah model dialog yang berbasis tradisi atau dalam terminologi Islam disebut dengan 'Urf. Selain itu, tradisitradisi ini memperlihatkan bagaimana aspek lingkungan (environment) yang melibatkan penerimaan tuan rumah dan kesesuaian di dalamnya, disadari atau tidak, terjadi kontak ideologi asimilatif di mana pendatang mengadopsi praktikpraktik budaya setempat dan tuan rumah menghormati praktik-praktik budaya yang berbeda dengan mereka. Aspek penting lainnya dalam tradisi ini adalah adanya kecenderungan (predisposition) host (Hindu) dan social ethics (Muslim) dengan segala macam pengalaman hidup yang mereka miliki, berusaha untuk dapat hidup kerukunan dan kedamaian.

Fenomena ini menanamkan keyakinan, bahwa perbedaan agama dan budaya dari pemeluk agama Hindu dan Islam, dapat disatukan sekaligus memperkokoh kerukunan antarumat beragama melalui 'urf (kearifan lokal). Begitu penting dan strategisnya nilai kearifan lokal dalam pembangunan bangsa, maka sangat wajar bila dialektika antara umat Hindu dan Muslim memfokuskan aktivitasnya pada penggalian nilai-nilai kearifan lokal (etnopedagogi) yang hidup di dalam masyarakat dan budaya Indonesia yang Berbhinneka Tunggal Ika (Azra, 2003). Lebih jauh lagi, proses dialektika melalui tradisi atau 'urf itu merupakan pengejawantahan dari filosofi Tri Hita Karana (tiga penyebab kebahagiaan) yaitu Parahyangan, Pawongan, dan Palemahan yang akan mewujud pada adagium luhur Bali yaitu Tat Twam Asi (kau adalah aku dan aku adalah kau). Tiga penyebab kebahagiaan itu adalah:

\section{a. Parahyangan}

Parahyangan, bermakna hubungan harmonis antara manusia dengan Tuhan Yang Mahaesa. Masyarakat Jembrana baik yang beragama Hindu 
atau Islam sangat menjunjung tinggi nilai-nilai keagamaan. Hal ini terlihat pada setiap upacara keagamaan seperti Galungan, Kuningan, dan Nyepi, mereka terlihat khusuk dalam melakukan peribadatannya. Bahkan terkadang sulit membedakan-untuk menyatakan tidak ada perbedaan-antara yang benar-benar 'alim dengan yang hanya sekadar ikutikutan saja. Fenomena seperti ini menjadi pemandangan yang sangat lazim terlihat di Jembrana. Menurut Arsana, fenomena ini disebabkan oleh pemahaman terhadap Parahyangan yang kuat dan ditanamkan dalam pendidikan agama keluarga (Wawancara dengan I Komang Arsana, 4 April 2019). Penanaman pendidikan agama tentu saja akan bermuara pada kepribadian manusia yang berkarakter luhur. Pembangunan dan pengembangan karakter melalui pendidikan agama, menghasilkan pribadi-pribadi yang secara fisik, emosi, sosial, kreativitas, spiritual, dan intelektual terjalin utuh, dapat berfungsi secara optimal, serta siap-tanggap dalam menghadapi problematika kehidupan dalam masyarakat. (Ramdhani, 2014)

Sedangkan bagi umat Muslim Jembrana, unsur Parahyangan ini sejalan dengan konsep Hablum min Allah, bermakna menjaga hubungan kepada Allah dengan selalu melaksanakan segala perintah-Nya dan meninggalkan segala larangan-Nya. Alur hubungan antara manusia dengan Allah Swt. dalam ajaran Islam, bersifat timbal-balik, yaitu bahwa manusia melakukan hubungan dengan Tuhan dan Tuhan juga akan melakukan hubungan dengan manusia. Tujuan hubungan manusia dengan Allah adalah dalam rangka pengabdian kepada-Nya melalui ritual-ritual ibadah. (QS.51:5). Fenomena kehidupan beragama masyarakat Muslim Jembrana sama dengan daerah lain di Indonesia, yaitu dengan intensitas beribadah cukup tinggi, sekalipun mereka merupakan kelompok minoritas. Menurut Muzakki, yang juga ketua Majelis Ulama Indonesia (MUI), sekaligus pengasuh Pondok Pesantren Manba'ul Ulum Jembrana menyatakan bahwa aktivitas beribadah umat Muslim di Jembrana sangat intents, nyaman, dan tertib, bahkan dalam aktivitas keagamaannya, seolah-olah mereka bukanlah umat minoritas di Jembrana, mereka (Muslim) dengan nyaman menunjukkan identitas keislaman yang mewarnai wilayah Jembrana (Wawancara dengan KH. Ahmad Muzakki, tanggal 2 Mei 2019).

Dalam ibadah mahdloh-aktivitas salat 5 (lima) waktu yang dilaksanakan di masjid-masjid ataupun musala-menurut ulama karismatik Jembrana itu, sangat ramai dan didukung oleh masyarakat di sekitar masjid atau musala, sekalipun pada tatanan demografinya tidak semua penduduk yang berada di sekitar lingkungan tersebut beragama Islam. Banyak di antara para penduduk di sekitar rumah ibadah tersebut beragama Hindu. Menjelang waktu salat subuh misalnya, seluruh masjid dan musala di wilayah Kabupaten Jembrana membunyikan pengeras suara, entah itu membaca wiridan, syi'iran, atau menyalakan CD yang berisi lantunan ayat al-Qur'an (qariah). Menjadi sebuah kebiasaan atau tradisi di wilayah Jembrana, bahwa masjid atau musala membunyikan pengeras suara untuk pengajian dan lain sebagainya di waktu subuh, satu jam sebelum masuknya waktu salat. Hal ini jelas bisa mengganggu waktu istirahat malam, akan tetapi sampai sejauh ini, konflik atau keberatan akan tradisi tersebut tidak pernah terjadi.

Menurut penulis, kesan Islam sebagai agama minoritas di wilayah Jembrana sama sekali tidak terlihat, berbeda dengan daerah lain di pulau Bali. Keunikan dari hasil asimilasi sosial antara umat Hindu dan Muslim di Jembrana ini yang membuat mereka berbeda dengan umat Hindu dan Muslim yang menempati 
wilayah lain di pulau Bali, apalagi mereka yang berada di luar Bali. Misalnya dalam peringatan Hari Raya Idul Adha dan Hari Raya Galungan yang dilaksanakan di Masjid Majapahit Banyubiru yang berdampingan dengan Pura Majapahit yang terletak di Desa Baluk Kecamatan Negara. Ketika pelaksanaan Hari Raya Idul Adha, maka untuk menghormati warga yang beragama Hindu di sekitar Pura Majapahit, Masjid Majapahit serta warga Muslim setempat tidak menyembelih sapi sebagai hewan kurban. Karena sapi adalah salah satu hewan yang disucikan oleh umat Hindu. Mereka menggantinya dengan kambing atau kerbau. Hal yang sama juga berlaku ketika perayaan Hari Raya Galungan, masyarakat warga Pura Majapahit, untuk menghormati warga Muslim di sekitar Pura dan Masjid Majapahit ini, tidak akan menyembelih hewan babi, karena dalam Islam babi adalah salah satu hewan yang diharamkan. Gambaran toleransi beragama seperti ini, bisa jadi jarang tidak ditemukan-untuk tidak mengatakan tidak ada-pada daerah lain di Indonesia.

Demikian juga dengan ibadah ghairu mahdloh (ibadah dalam pengetahuan umum yang tujukan untuk kemaslahatan, kesuksesan, dan keuntungan umat manusia), sama sekali tidak terkesan ada batas, jarak, atau waktu tertentu bagi umat Islam dan umat lainnya dalam beribadah. Mereka semua dengan tenang dapat melaksanakan aktivitas keagamaan tanpa ragu menunjukkan identitas kesukuan, keagamaan, dan tradisi yang mengikutinya (karena banyak dari tradisitradisi itu tidak berasal dari Jembrana).

Menurut I Made Kembang Hartawan, yang juga wakil Bupati Kabupaten Jembrana, menjelaskan, bahwa kehidupan beragama yang sehat di seluruh wilayah Jembrana disebabkan oleh beberapa faktor, antara lain: Pertama, adanya kedewasaan dalam beragama. Menurutnya, apabila tingkat kedewasaan beragama masyarakat Jembrana dangkal atau bahkan tipis, bisa jadi suara-suara yang berasal dari masjid atau musala terutama pada waktu subuh, akan mengganggu aktivitas tidur mereka. Terlebih di bulan puasa, terkadang terdapat beberapa masjid atau musala yang melakukan tadarus mulai setelah selesai salat tarawih sampai waktu sahur; Kedua, pemahaman akan pentingnya pengamalan konsep pluralisme. Masyarakat Jembrana yang multi-etnis, multi-agama-sekalipun Hindu sebagai agama dominan-, tidak merasa terganggu dengan aktivitas beribadah umat lain, karena masingmasing dari mereka beranggapan, jika seseorang dekat dengan Tuhannya, maka tentunya seseorang tersebut akan menjadi bijaksana dan semakin toleran. Apalagi, sebagaimana dikatakan oleh Hartawan, tidak ada satu agama apa pun yang mengajarkan kekerasan. Wakil Bupati Jembrana itu pun menuturkan, "Saya sering membantu pembangunan masjid, pondok pesantren, musala, sekalipun saya beragama Hindu, karena bagi saya urusan surga dan neraka biar Tuhan yang atur, yang penting kita berbuat baik kepada sesama." (Wawancara dengan I Made Kembang Hartawan, 14 April 2019).

Fenomena keberagamaan seperti yang diuraikan oleh I Made Kembang Hartawan, terasa berbeda dengan fenomena keberagamaan sekarang di daerah lain. Semakin tinggi aktivitas keagamaannya, semakin terkesan eksklusif, sombong, dan menganggap salah dan rendah orang lain yang berbeda cara beragamanya (Gellner, 1992). Bahkan menganggap agama lain adalah agama rendah, diikuti dengan cacian, makian, serta hinaan terhadap aktivitas keagamaan orang lain.

b. Pawongan

Filosofi Tatwan Asi, menjadi landasan dalam interaksi masyarakat Jembrana dalam menjalani aktivitas 
kehidupan sehari-hari. Tat Wam Asi, yang berarti kau adalah aku dan aku adalah kau, menjadi pijakan dasar dalam unsur pawongan, yaitu membangun hubungan harmonis antar sesama manusia dengan tanpa membedakan suku, agama, ras, dan golongan. Bukti sahih implementasi unsur pawongan, adalah adanya hubungan menyama-braya (persaudaraan) yang erat, kemudian agawe suka ning len (berusaha membuat orang lain suka). Unsur pawongan yang terimplementasi dalam menyama-braya, bisa dilihat dari tradisi ngejot. Ngejot ini diartikan sebagai bentuk hubungan harmonis masyarakat Hindu dan Islam. Dalam hal ini, ditekankan agar sesama umat beragama untuk selalu mengadakan komunikasi dan hubungan yang harmonis melalui kegiatan Sima Krama Dharma Santhi, yang dalam terminologi Islam disebut silaturrahmi.

Kegiatan ini dipandang penting dan strategis, mengingat kecenderungan manusia ingin selalu hidup berdampingan dan tidak bisa hidup sendirian. Sekalipun pada beberapa daerah di Bali unsur pawongan belum dapat dikatakan berjalan dengan baik-di disebabkan oleh masih banyaknya adat-istiadat yang kaku dan masih sangat kuat berlaku di kalangan umatHindu-tetapi untuk kasus Jembrana, adat tidak mejadi penghalang dalam membangun hubungan yang harmonis antar sesama umat manusia. Di Bali pada umumnya, keberadaan adat-istiadat yang kaku dengan selalu menampilkan rigiditas yang tinggi, terkadang menjadi sumber ketidakharmonisan hubungan antar wangsa dalam intern umat Hindu sendiri. Ada warga yang mengklaim sebagai wangsa yang berkasta paling tinggi hanya berdasarkan keturunan yang tidak menggunakan konsep agama sebagai landasan acuannya. Hal ini tentu saja tidak akan dapat menumbuhkan keharmonisan, jika masih ada suatu wangsa yang arogan, mengklaim diri paling bermartabat. Sejalan dengan hal tersebut, Dharma Putra berpendapat bahwa untuk kasus Bali, memang adatlah yang terkadang menjadi sumber konflik, bukan agama.

Dharma Putra menambahkan bahwa warga Jembrana sangat menjunjung tinggi norma-norma sosial, baik yang bersumber dari agama maupun yang bersumber dari adat istiadat. Norma-norma dalam pergaulan sehari-hari itu adalah menghargai dan menghormati orang lain, baik itu orang yang dikenal maupun orang yang tidak di kenal. Warga Jembrana yang beragam Hindu misalnya, akan menyapa orang yang belum dikenalnya dengan sebutan Gus, kata-kata Gus ini berasal dari Bagus, sebagai penghargaan atau penghormatan setinggi-tingginya kepada orang lain. Terlebih lagi di sekolah-sekolah, guruguru menggunakan kata Gus untuk menyapa dan menegur peserta didiknya (Wawancara dengan Ida Bagus Dharma Putra, 17 April 2019).

Demikian juga dengan umat Islam, dalam menyapa orang yang belum dikenalnya dengan sebutan mad atau mat, berasal dari kata Muhammad yang dinisbahkan kepada arti nama itu sendiri yaitu orang yang terpuji. Bagi warga Muslim Jembrana, panggilan mad ini dimaksudkan untuk tidak menyinggung atau membuat perasaan orang yang belum dikenalnya menjadi terganggu ataupun risih ketika mereka disapa. Dharma Putra, juga menambahkan, bahwa panggilan gus atau mad ini berlangsung sejak ratusan tahun silam dan mengakar sampai hari ini di Jembrana, sehingga menjadi kearifan lokal tersendiri yang bernilai tinggi. Melalui budaya seperti ini dapat menumbuhkan semangat kekeluargaan yang tinggi pada semua masyarakat yang ditinggal wilayah Kabupaten Jembrana.

\section{c. Palemahan}

Selain unsur Parahyangan dan unsur Pawongan, dalam Tri Hita Karana, ada unsur yang tidak kalah pentingnya, yaitu 
unsur Pelemahan yang berarti menjalin hubungan yang harmonis antara umat manusia dengan alam lingkungannya. Ajaran ini menekankan kepada umat manusia untuk tetap menjaga kelestarian lingkungan alam sekitar, sehingga terwujud keharmonisan alam, dan terjaganya keseimbangan ekosistem; seperti tumbuh-tumbuhan, binatang, dan hal-hal lain yang bersifat skala-niskala (nyata/tidak nyata). Dalam ajaran agama Hindu, unsur pelemahan diwujudkan dengan ritual Bhuta Yadnya (upacara persembahan suci yang tulus ikhlas kehadapan unsur-unsur alam). Contoh yang biasa diterapkan dalam unsur pelemahan, yaitu; tawur agung, dengan tujuan untuk menjaga keseimbangan, kelestarian antara jagat raya dengan manusia (keseimbangan antara makrokosmos dengan mikrokosmos).

Bagi masyarakat Jembrana, sudah menjadi sebuah keharusan untuk merawat dan menjaga alam dengan bersih, rapi, indah, dan sehat, seperti tidak menebang pohon sembarangan (illegal logging), pencemaran udara, pencemaran air, menata taman-taman agar terlihat menarik, dan lain-lain. Fenomena seperti ini menjadi sesuatu yang biasa terjadi (lumrah) pada masyarakat Bali pada umumnya. Maka tidaklah juga mengherankan, apabila masyarakat Bali menolak reklamasi di teluk Benoa, karena menurut mereka, reklamasi itu bertentangan dengan unsur Palemahan yang dapat merusak hubungan harmonis antara manusia dengan alam sekitarnya (makrokosmos dan mikrokosmos).

Salah satu wujud dari konsepsi Palemahan di Jembrana dan Bali pada umumya adalah adanya subak. Subak adalah perkumpulan petani yang mengelola air irigasi di lahan persawahan yang berkembang menjadi hukum adat berkarakter sosio-agraris-religius. Pada perkembangan selanjutnya, subak diperluas makna dan karakteristik di dalamnya, menjadi sebuah perkumpulan para petani yang bertugas mengatur pembagian air yang memiliki karakter sosio-teknis-religius. Pengembangan karakteristik dari subak, dikarenakan bertambahnya cakupan aktivitas yang meliputi teknis pertanian dan teknis irigasi. Dalam organisasi subak, pemanfaatan air dan pemeliharaan lingkungan menjadi unsur dari pelemahan yang sangat dijaga. Regulasi dalam subak mampu mengorganisasi dan mengelola sistem irigasi dengan dasar-dasar harmoni dan kebersamaan sesuai dengan prinsip konsep Tri Hita Karana. Dengan dasar itu, sistem subak mampu mengantisipasi kemungkinan kekurangan air (khususnya pada musim kemarau) dengan mengelola pelaksanaan pola tanam sesuai dengan peluang keberhasilannya atau mengikuti perkembangan pasar.

Subak sebagai lembaga yang berwatak sosio-kultural memiliki kekuatan dan kearifan yang fleksibel dan mampu menyerap berbagai pembaharuan teknologi pertanian serta menyesuaikan kegiatannya dengan kebudayaan yang berkembang pada masyarakat sekitarnya. Dengan demikian, setiap kegiatan dalam subak selalu mencerminkan keseimbangan hubungan yang harmonis dan serasi sesama manusia, manusia dengan lingkungan, dan manusia dengan Tuhan. Upacaraupacara atau selamatan untuk meminta keselamatan dari Tuhan di setiap akan mulai ke sawah merupakan unsur dari Parahyangan. Subak juga merupakan sarana silaturrahmi antar warga sekaligus menjadi sarana untuk saling berbagi (air) dalam melestarikan serta mencari nafkah.

Jika dilihat dalam Islam, konsepsi Tri Hita Karana, juga merupakan inti dari ajaran Islam, yaitu pembinaan akhlak. Islam menekankan ajaran ihsan atau kebaikan serta berbuat yang terbaik 
kepada semua pihak dengan tidak membeda-bedakan suku, agama, ras, dan golongan. Bermula terhadap Tuhan, makhluk-makhluk yang berakal, sampai kepada makhluk-makhluk yang tak berakal. Kehadiran Nabi Muhammad saw., membawa ajaran yang tujuan utamanya adalah mengajak manusia untuk melakukan sesuatu yang terbaik (berakhlak) kepada sesama makhluk ciptaan Tuhan, sesuai dengan sabda beliau:

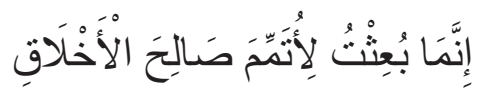

Sesungguhnya aku diutus tidak lain, kecuali untuk menyempurnakan akhlak yang saleh.

Kenyataan ini menunjukkan,
bahwa beliau ditugaskan untuk
menyempurnakan berbagai bidang
akhlak yang dilandasi dengan budi
pekerti dan moral. Berakhlak dalam
berinteraksi-sebagaimana diajarkan
oleh Nabi-tidak saja kepada sesama
Muslim, tetapi kepada semua manusia
tanpa memandang agama, ras, suku, dan
golongan, bahkan kepada semua ciptaan
Tuhan (Shihab, 2018).

Dalam agama Hindu, perintah untuk saling mengasihi dan toleransi terhadap sesama, terdapat dalam Dasa Yama Brata, yang berarti sepuluh langkah pengendalian diri untuk mencapai kesempurnaan hidup dan kesucian baik lahir maupun batin yang berupa dharma dan moksa. Ajaran ketujuh dari Dasa Yama Brata ini disebut Priti, memiliki makna hendaknya seseorang memiliki sifat welas asih, yaitu sifat kasih sayang kepada semua makhluk Tuhan. Ajaran Priti juga menekankan bahwa kebencian harus dibalas dengan kasih sayang, karena kebencian tidak akan pernah berakhir jika dibalas dengan kebencian juga (Suparta, 2009). Pentingnya penerapan akhlak dalam berinteraksi kepada masyarakat sangat ditekankan oleh Nabi Muhammad saw. hal ini didasarkan pada sabdanya:

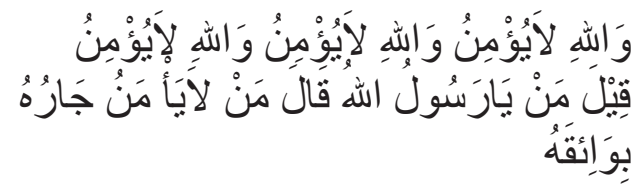

Demi Allah. Ia tidak beriman. Demi Allah ia tidak beriman. Demi Allah ia tidak beriman. "ada yang bertanya: "siapa, wahai Rasul?" beliau menjawab: "yang tidak aman tetangganya dari kejahatannya dan gangguannya."

Dari hadis di atas, jelas disebutkan bahwa Muhammad saw-sebagai seorang Nabi pembawa risalah terakhir-sangat menganjurkan penerapan budi pekerti yang baik kepada masyarakat di mana pun dia berada. Iman dan akhlak, jika diterapkan dengan sempurna, maka kemudian melahirkan rasa malu. Malu yang dimaksud di sini adalah malu untuk melakukan tindakan-tindakan yang tidak diridai oleh Tuhan. Tindakan yang tidak diridai oleh Tuhan, secara umum dikatakan adalah perbuatan yang tidak menjaga hubungan baik dengan Tuhan, tidak menjaga hubungan baik kepada manusia, dan tidak menjaga hubungan yang baik kepada alam sekitar, yang oleh orang Jembrana dikatakan Parahyangan, Pawongan, dan Palemahan.

Secara tegas Nabi Muhammad saw, mengaitkan hubungan antara iman dan malu serta dengan senantiasa melakukan penghormatan kepada tamu dan lain sebagainya melalui sabda beliau:

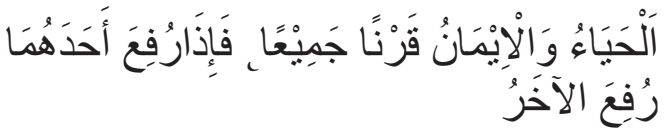

Malu dan iman bergandengan bersama. Kalau salah satu tiada, maka yang lain pun (turut) tiada.

Iman dan malu, keduanya mendorong pemiliknya untuk melakukan kebajikan dan berakhlak yang mulia, serta menghindarkannya dari keburukan dan kebejatan. Di Jembrana, sebagaimana diungkapkan oleh KH. Muzakki, dari sekian banyak lembaga pendidikan Islam, 
selalu mengajarkan kepada umat Muslim agar selalu meningkatkan keimanan dan ketakwaan kepada Tuhan dengan menjadikan rasa malu sebagai landasan utamanya. Malu yang dimaksud adalah, rasa malu untuk berbuat kejelekan, malu tidak dapat membantu orang lain, malu untuk bertindak semena-mena kepada yang lain, malu bersikap tidak adil, dan hal-hal lain yang berhubungan dengan negative social behavior di tengah masyarakat (Wawancara dengan KH. Ahmad Muzakki, 2 Mei 2019).

Dalam Perspektif Teori Komunikasi integratif yang dikemukakan oleh Kim Young Yun, keempat kearifan tradisi yang mewujud pada kearifan lokal ini bertujuan untuk menumbuhkan pemahaman mendalam dari masing-masing tradisi (deep understanding to each other). Dalam tradisi male, terlihat bahwa aspek kognitif terbangun melalui pemahaman umat Islam kultural akan pentingnya berkomunikasi sebelum mengadakan satu kegiatan keagamaan. Hal ini bisa dilihat dalam aktivitas mengarak male keliling kampung yang bertujuan untuk mengabarkan umat Hindu sebagai umat mayoritas (tuan rumah) bahwa umat Muslim mohon izin sedang melaksanakan kegiatan keagamaan. Dari sini kemudian memunculkan rasa simpati dan empati dari umat Hindu untuk melibatkan Pecalang dalam kegiatan mengarak male yang dalam aspek operasionalnya menggunakan atribut bercorak Hindu (pager uyung). Di sini terlihat bagaimana model komunikasi yang ditunjukkan umat Hindu sebagai tuan rumah dalam menciptakan sebuah komunikasi (host social communication) dengan mengedepankan aspek komunikasi sosial etnis (ethnic social communication) secara interpersonal dan komunikasi massa.

Demikian juga dalam tradisi male, ngejot, rebana, dan mekepung, empat faktor teori komunikasi integratif berjalan dengan baik. Meskipun tradisi ngejot dan mekepung merupakan tradisi asli umat Hindu, tetapi dalam aktivitasnya menyesuaikan dengan tradisi dan budaya umat Islam sebagai warga pendatang. Begitu juga umat Islam memodifikasi tradisi tersebut untuk dapat diterima dalam lingkungan masyarakat (Islam). Umat Hindu tidak akan ngejot makanan yang tidak diharamkan oleh agama Islam, seperti daging anjing, babi, dan lain-lain, begitu pula umat Islam dalam setiap kegiatan keagamaan atau hajatan (selamatan) selalu ngejot makanan kepada umat Hindu dengan mendasarkan pada aspek lingkungan setempat. Dalam tradisi rebana juga demikian, memang syair yang dilantunkan semua bernapaskan Islam, tetapi musik pengiringnya bernuansa Hindu. Inilah yang dimaksud dengan ideologi asimilatif, yaitu mendorong adanya kesesuaian, dan ideologi pluralis, yaitu mendorong adanya kekhasan etnis. Umat Muslim sebagai warga minoritas berusaha menyesuaikan diri dengan lingkungan, dan umat Hindu sebagai warga mayoritas berusaha untuk selalu mengedepankan nilai etika, sosial, bahkan ekonomi agar terjadi kontak sosial yang baik.

\section{SIMPULAN}

'Urf, (kearifan lokal) atau dan atau tradisi merupakan salah satu usaha kedua umat beragama untuk berdialog dengan menggunakan akal budinya (kognisi) untuk dapat bertindak dan bersikap terhadap suatu objek atau peristiwa yang terjadi dalam ruang tertentu. Beberapa kearifan lokal yang dijadikan sarana dalam menciptakan keharmonisan di Jembrana adalah melalui tradisi Male, Ngejot, Rebana, dan Mekepung. Tradisitradisi ini telah mengalami asimilasi yang telah berlangsung lama, sehingga terjadi proses transformasi antar budaya (intercultural transformation), berfungsi sebagai sebuah ruang berkomunikasi dan 
berinteraksi (dialog) yang melibatkan suatu pola-pola hubungan antara manusia dengan manusia atau manusia dengan lingkungan fisiknya, serta memiliki nilainilai tersendiri yang diyakini memiliki kebenaran sekaligus menjadi acuan dalam bertingkah-laku sehari-hari masyarakat Jembrana.

Tradisi-tradisi ini juga merupakan pengejawantahan dari filosofi sosiologis masyarakat Jembrana, yaitu Tri Hita Karana (tiga penyebab kebahagiaan), meliputi: Parahyangan, Pawongan, dan Palemahan. Selanjutnya dari pengamalan ketiga filosofi tersebut, hubungan antara umat Islam dan Hindu di Bali semakin erat di mana hal ini merupakan wujud pengamalan dari adagium agung di Bali yaitu Tatwam Asi (kau adalah aku dan aku adalah kau). Dengan demikian makna yang terkandung dalam tradisitradisi tersebut merupakan sarana untuk menjalin hubungan baik dengan tuhan (hablum min Allah), menjalin hubungan baik dengan manusia (hablum min annas), dan menjalin hubungan baik dengan alam (hablum min al-'alam) sehingga tercipta harmonisasi dan dialektika harmonis antar kedua umat beragama yang mengarah pada karakter humanis, toleran, dan inklusif, yang akhirnya mewujud pada proses asosiasi, integrasi, komplementasi dan sublimasi.

\section{UCAPAN TERIMA KASIH}

Puji Syukur senantiasa tercurahkan pada Allah Swt. berkat hidayah dan inayah-Nya, penulis dapat menyelesaikan tulisan ini dan dipublikasikan pada Jurnal Harmoni. Salawat dan salam semoga selalu tercurahkan kepada Nabi Besar Muhammad saw. semoga segala syafaatnya tercurahkan kepada seluruh umat Islam di dunia. Selanjutnya penulis berterima kasih kepada Kepala Balai Litbang Kementerian Agama RI, yang telah memfasilitasi publikasi penelitian ini. Terima kasih juga penulis ucapkan kepada reviewer yang dengan saksama telah memerikan dan mengarahkan sistematika penulisan agar menjadi lebih baik. Dalam proses penelitian ini, penulis banyak dibantu oleh beberapa pihak, antara lain: I Made Kembang Hartawan (Wakil Bupati Kabupaten Jembrana), KH. Ahmad Muzakki (Ketua MUI Jembrana), I Komang Arsana (Ketua FKUB dan PHDI Kabupaten Jembrana), KH. Ahmad Damanhuri (Sejarawan Muslim Jembrana), Ida Bagus Ketut Dhamar Santika Putra (Budayawan Jembrana), Ida Bagus Indagosa (Tokoh dan Mantan Bupati Jembrana), Ida Bagus Arnawa (Anggota DPRD Jembrana), Ali Rahman (Kepala Lingkungan Desa Pengambengan), kepada mereka semua penulis ucapkan terima kasih yang sebesar-besarnya semoga amal ibadanya diterima di sisi Tuhan Yang Mahaesa. 


\section{DAFTAR ACUAN}

Abdul Haq. (2009). Formulasi Nalar Figh (I). Surabaya: Kalista.

Al-Humaidy, M. A. (2017). Tradisi Mauludan: Pemaknaan Kontekstual Ritual Agama Masyarakat Pamekasan. ISTIQRO, 6(1), 76-84.

Al-Qarafi, A. al-A. A., \& Idris, I. (1998). Al-Furuq wa Anwar al-Buruq fi Anwa” al-Furuq. Kairo: Dar al-Kutub al-Arabiyah.

Azra, A. (2002). Reposisi Hubungan Agama dan Negara: Merajut Kerukunan Antarumat (I. Thaha, ed.). Jakarta: Kompas.

Azra, A. (2003). "Bali and Southeast Asian Islam: Debunking the Myths" dalam Kumar Ramakrishna dan See Seng Tan, eds., After Bali: The Threat of Terrorism in Southeast Asia. Singapore: World Scientific Publishing Co. Pte. Ltd.

Bailey, K. D. (1982). Methods of Social Research. New York: A Division of Macmillan Publishing Co. Inc.

Burhanuddin, Y. M. (2012). Bali Yang Hilang; Don't Let Bali Alone Againt Terorism. Yogyakarta: Kanisius.

Dharmayuda, I. M. S. (1995). Kebuayaan Bali: Pra Hindu, Masa Hindu, dan Pasca Hindu. Denpasar: Kayumas Agung.

Gellner, E. (1992). Postmodernism, Reason, and Religion. London: Rouledge.

Gudykunts, William B, K. Y. Y. (2003). Communicating with Stranger, Edition. USA: McGraw Hill Companies, Inc. (4 ed.). USA: Mc-Graw Hill Companies, Inc.

Khaldûn, A. al-R. I. (1992). Muqaddimah li Kitâb al-'Ibar wa Dîwân al-Mubtadâ wa al-Khabar fi Ayyâm al-'Arab wa al-'Ajam wa al-Barbar wa Man 'Âsharahum min Dzawi alShulthân al-Akbar. Beirut: Dâral-Kutubal-'Ilmiyyah.

Knopp, R. B. B. and S. (1998). Qualitative Research for Education: An Introduction to Theory and Methods. Boston: Allyn and Bacon.

Kuntowijoyo. (2001). Muslim Tanpa Masjid, Essai-Essai Agama, Budaya, dan Politik dalam Bingkai Strukturalisme Transendental. Bandung: Mizan.

Merriam, S. B. (2009). Qualitative Research: A Guide to Design and Implementation. USA: The Jossey-Bass.

Paisun. (2010). Dinamika Islam Kultural: Studi atas Dialektika Islam dan Budaya Lokal Madura. el-Harakah, 12(2), 154-168.

Peters, F. E. (1995). Muhammad and The Origin Of Islam. New York: Oxford University Press.

Ramdhani, M. A. (2014). Lingkungan Pendidikan dalam Implementasi Pendidikan Karakter. Jurnal Pendidikan Universitas Garut, 8(1), 28-37.

Saeed, A. (2016). Al-Qur'an Abad 21: Tafsir Kontekstual (Ervan Nur Tawab dan Ahmad Baikuni, ed.). Bandung: Mizan. 
Saihu, Abd. Aziz, Fatkhul Mubin, A. Z. S. (2020). DESIGN OF ISLAMIC EDUCATION BASED ON LOCAL WISDOM (An analysis of Social Learning Theories in Forming Character through NgejotTradition in Bali). International Journal of Advanced Science and Technology, 29(6), 1278-1293.

Saihu. (2019). PENDIDIKAN KARAKTER BERBASIS KEARIFAN LOKAL (STUDI DI JEMBRANA BALI). Edukasi Islami: Jurnal Pendidikan Islam, 8(1), 69-90.

Saihu, A. M. (2019). Teori pendidikan behavioristik pembentukan karakter masyarakat muslim dalam tradisi Ngejot di Bali. Ta'dibuna, 8(2), 168.

Saihu, M. (2019). Merawat Pluralisme Merawat Indonesia: Potret Pendidikan Pluralisme Agama di Jembrana-Bali. Yogyakarta: DEEPPUBLISH.

Shihab, M. Q. (2018). Yang Hilang Dari Kita adalah Akhlak. Ciputat: Lentera Hati.

Sudiatmaka, I. K. . H. \& K. (2016). Identifikasi Nilai-nilai Pendidikan Karakter Pada Tradisi Makepung Sebagai Sumber Belajar PPKN Di SMP N 4 Mendoyo (studi kasus di Desa Pakraman Delod Berawa. e-journal.undiksha, 2(1), 23.

Sumbulah, U. (2012). Islam Jawa dan Akulturasi Budaya: Karakteristik, Variasi dan Ketaatan Ekspresif. el-Harakah, 14(1), 51-68.

Suparta, M. (2009). Pendidikan Kedewasaan Beragama. Tangerang: Gifani Alfatana Sejahtera.

Widianingsih, I. (2014). Decentralized Governance and Delivery of Services: Lessons Learned from Jembrana District. Denpasar.

Widiyanto, T. S. \& Y. C. (2015). Developing a Community Revitalization Movement Based on Reflective Dialog Using Engaged Ethnography. Journal of Group Dynamics, 32, 104.

Zahid, M. (2006). Perpaduan Hukum Islam dan Hukum Adat (Upaya Merumuskan Hukum Islam Berkepribadian Indonesia). Jurnal al-Ihkam, 1(1), 61.

Wawancara:

Damanhuri, Ahmad. (2019, Maret 7)

Putra, Ida Bagus Komang Dharma Santika. (2019, April 7, Mei 1)

Muzakki, Ahmad. (2019, Maret 4, Mei 2)

Arnawa, Ida Bagus (2019, April 7)

Arsana, I Komang, (2019, April 4, 7)

Rahman, Ali. (2019, April 7)

Asmari. (2019, April 9)

Indagosa, Ida Bagus (2019, April 9)

Hartawan, I Made Kembang (2019, April) 